Rafał Dubowski

\title{
Sąd nad przedsądem. Ocena propozycji zniesienia instytucji przedsądu w świetle danych empirycznych (druk sejmowy nr 2697) ${ }^{1}$
}

The court over the pre-court. Assessment of the proposal to abolish the pre-trial institution in the light of empirical data (Sejm's paper no. 2697): In the context of the presented bill there is a conflict of two socially and legally significant values. One of them is the rapidity of proceedings before the Supreme Court, while the other one is the need to ensure protection of the rights and interests of entities submitting cassation complaint, in case such rights and interests have been violated as a result of the appealed decision. The abolition of the institution of a pre-trial and the transfer of all cassation appeals to the substantive recognition by the Supreme Court will cause a significant increase in the number of pending civil cases and will also extend the average duration of proceedings before the Supreme Court. In order to implement the proposed regulations, the possibility of increasing the number of judges or judicial assistants in the Civil Chamber and the Chamber of Labor and Social Insurance should be considered.

Keywords: Code of Civil Procedure, impact assessment, bill

Słowa kluczowe: Kodeks postępowania cywilnego, ocena skutków regulacji, projekt ustawy

Doktor nauk prawnych, ekspert ds. legislacji BAS - rafal.dubowski@sejm.gov.pl • https://orcid.org/0000-0001-7852-4275

\section{Przedmiot opinii}

Przedmiotem opinii są skutki, które będzie rodzić lub może powodować wprowadzenie regulacji zawartej w komisyjnym projekcie ustawy o zmianie ustawy Kodeks postępowania cywilnego (druk nr 2697); dalej: projekt. Ocena uwzględnia stan prawny na dzień 23 sierpnia $2018 \mathrm{r}$.

1 Opinia Ocena skutków regulacji zawartej w komisyjnym projekcie ustawy o zmianie ustawy - Kodeks postępowania cywilnego (Druk nr 2697) sporządzona 10 września 2018 r. na zlecenie zastępcy Szefa Kancelarii Sejmu; BAS-WAP 2042/18. 


\section{Zakres proponowanych zmian}

Projekt ma na celu umożliwić Sądowi Najwyższemu (SN) przyjmowanie do rozpoznania każdej dopuszczalnej pod względem formalnym skargi kasacyjnej w sprawie cywilnej, bez wstępnej kontroli skargi w postaci tzw. przedsądu, sprawowanego przez SN w składzie jednego sędziego. Ponadto projekt przewiduje uchylenie art. $398^{16}$ ustawy z 17 listopada 1964 r. - Kodeks postępowania cywilnego (t.j. Dz.U. 2018, poz. 1360, ze zm.; dalej: k.p.c.), umożliwiającego SN orzekanie co do istoty sprawy oraz uchylenie art. $398^{19}$ k.p.c., który przesądza, że w sytuacji, gdy pozew ulegał odrzuceniu albo istniała podstawa do umorzenia postępowania, SN uchyla wydane w sprawie wyroki oraz odrzuca pozew lub umarza postępowanie. Jak wyjaśniono $\mathrm{w}$ uzasadnieniu projektu: $w$ przypadku merytorycznego rozpatrywania skarg kasacyjnych jedynym dopuszczalnym rozstrzygnięciem, w przypadku uznania przez Sąd Najwyższy skargi za zasadna, powinno być uchylenie zaskarżonego orzeczenia i przekazanie sprawy do ponownego rozpatrzenia właściwemu sądowi².

\section{Podmioty, na które będzie oddziaływać regulacja zawarta w projekcie}

Regulacja zamieszczona w projekcie, w razie jej wprowadzenia, bezpośrednio wpływać będzie na Sąd Najwyższy oraz na każdego, kto wniesie skargę kasacyjną w sprawie cywilnej do tego sądu.

\section{Ocena skutków proponowanych rozwiązań}

Instytucja przedsądu w obecnym kształcie została wprowadzona przez art. 1 pkt 13 ustawy z 22 grudnia 2004 r. o zmianie ustawy - Kodeks postępowania cywilnego oraz ustawy - Prawo o ustroju sądów powszechnych (Dz.U. 2005, nr 13, poz. 98). Przedmiotowa nowelizacja weszła w życie z dniem 6 lutego $2005 \mathrm{r}$.

W świetle obowiązującego art. $398^{9} \$ 1$ k.p.c. oceniana w ramach przedsądu skarga kasacyjna zostaje przyjęta do rozpoznania, jeżeli:

- w sprawie występuje istotne zagadnienie prawne,

- istnieje potrzeba wykładni przepisów prawnych budzących poważne wątpliwości lub wywołujących rozbieżności w orzecznictwie sądów,

- zachodzi nieważność postępowania lub

- skarga kasacyjna jest oczywiście uzasadniona.

2 Uzasadnienie komisyjnego projektu ustawy o zmianie ustawy - Kodeks postępowania cywilnego, druk sejmowy nr 2697/VIII kad., s. 1; dalej: uzasadnienie. 
O przyjęciu lub odmowie przyjęcia skargi kasacyjnej do rozpoznania SN orzeka w składzie jednego sędziego na posiedzeniu niejawnym (art. $398^{9} \$ 2$ k.p.c. oraz art. $398^{10}$ k.p.c.).

Motywując potrzebę wprowadzenia przedstawionych w projekcie zmian, w uzasadnieniu wskazano, że obowiązujące przepisy formułujące przesłanki przyjęcia skargi kasacyjnej do rozpoznania stwarzają „ogromne pole do swobodnej, a wręcz arbitralnej interpretacji”, a przez to sędzia wydający na posiedzeniu niejawnym - niepodlegające zaskarżeniu - postanowienie o (nie)przyjęciu skargi dysponuje „ogromną i niekontrolowaną w żaden sposób władzą" (uzasadnienie, s. 2-3). W związku z tym w ocenie projektodawców likwidacja przedsądu przyczyni się do wzrostu zaufania obywateli do państwa oraz poprawi przejrzystość systemu prawnego (uzasadnienie, s. 3).

Aby właściwie zdiagnozować spodziewane skutki przyjęcia rozwiązań zaprezentowanych w projekcie, a w szczególności ich wpływ na pracę SN, warto przeanalizować dane empiryczne dotyczące funkcjonowania przedsądu w latach 2005-2017, tj. od roku, w którym wprowadzono tę instytucję w obecnym kształcie, do roku, za który możliwe jest przedstawienie pełnych danych. W latach tych skargi kasacyjne w sprawach cywilny rozpatrywały dwie izby: Izba Cywilna i Izba Pracy, Ubezpieczeń Społecznych i Spraw Publicznych, dlatego poniżej w osobnych tabelach zestawiono dane odnoszące się do obu izb. Tam, gdzie było to konieczne, dane zostały zaokrąglone do najbliższej wartości całkowitej.

Z danych przedstawionych w tabelach 1 i 2 wynika, że w latach 2005-2017 średnio w każdym roku Izba Cywilna SN załatwiała 2847 spraw ze skarg kasacyjnych, z czego średniorocznie $60 \%$ z nich załatwiano przez odmowę przyjęcia skargi kasacyjnej do rozpoznania. Mimo tego w badanym okresie przeciętnie 1276 spraw pozostawało do rozpoznania w kolejnym roku.

Z kolei, jak pokazują dane zamieszczone w tabelach 3 i 4, tylko nieznacznie odmiennie prezentowała się sytuacja w Izbie Pracy, Ubezpieczeń Społecznych i Spraw Publicznych. W latach 2005-2017 średnio w każdym roku Izba ta załatwiała 1876 spraw ze skarg kasacyjnych, z czego średniorocznie $57 \%$ z nich załatwiano przez odmowę przyjęcia skargi kasacyjnej do rozpoznania. Mimo tego w badanym okresie przeciętnie 1125 spraw pozostawało do rozpoznania w kolejnym roku.

Mając na uwadze wszystkie analizowane dotąd dane - dotyczące zarówno Izby Cywilnej, jak i Izby Pracy, Ubezpieczeń Społecznych i Spraw Publicznych można przypuszczać, że zniesienie instytucji przedsądu i przekazanie wszystkich skarg kasacyjnych do merytorycznego rozpoznania przez SN w składzie trzech sędziów spowoduje znaczny przyrost liczby zaległych spraw cywilnych i tym samym wydłuży przeciętny czas trwania postępowania przed SN.

Przy czym wydaje się, że nie miałoby na to wpływu uchylenie - zgodnie $\mathrm{z}$ propozycją zawartą w projekcie - art. $398^{19}$ k.p.c. (przewidującego, że w przypadku gdy pozew ulegał odrzuceniu albo istniała podstawa do umorzenia postę- 


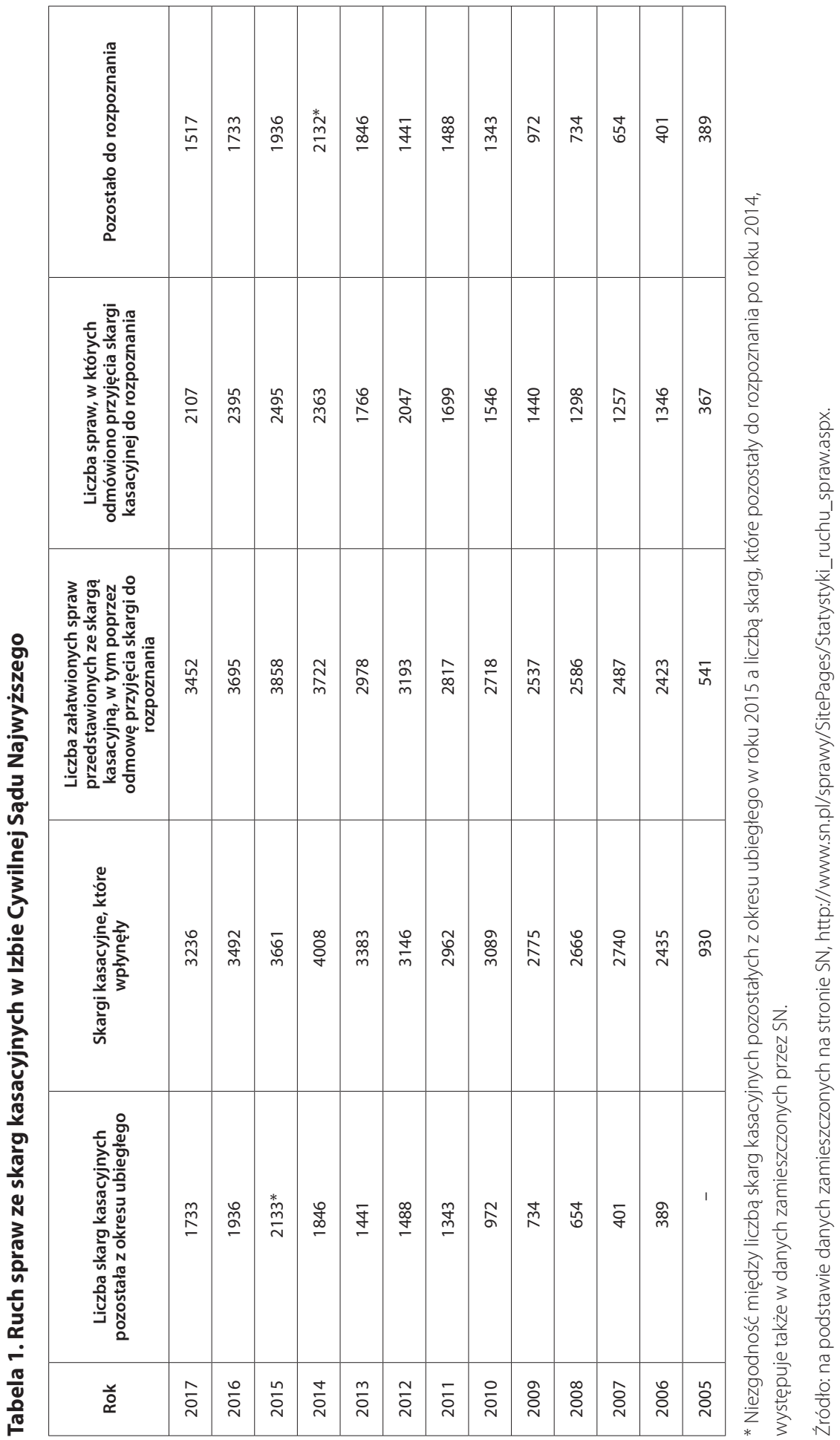


Tabela 2. Odsetek spraw ze skarg kasacyjnych załatwionych przez odmowę przyjęcia skargi kasacyjnej do rozpoznania w Izbie Cywilnej Sądu Najwyższego

\begin{tabular}{|c|c|}
\hline Rok & $\begin{array}{c}\text { Odsetek spraw ze skarg kasacyjnych } \\
\text { załatwionych przez odmowę przyjęcia } \\
\text { skargi kasacyjnej do rozpoznania }\end{array}$ \\
\hline 2017 & 61 \\
\hline 2016 & 65 \\
\hline 2015 & 65 \\
\hline 2014 & 63 \\
\hline 2013 & 59 \\
\hline 2012 & 64 \\
\hline 2011 & 60 \\
\hline 2010 & 57 \\
\hline 2009 & 57 \\
\hline 2008 & 50 \\
\hline 2007 & 51 \\
\hline 2006 & 56 \\
\hline 2005 & 68 \\
\hline
\end{tabular}

Źródło: jak pod tabelą 1.

powania, SN uchyla wydane w sprawie wyroki oraz odrzuca pozew lub umarza postępowanie) oraz uchylenie art. $398^{16}$ k.p.c. (umożliwiającego SN orzekanie co do istoty sprawy).

Ponieważ w uzasadnieniu projektu wskazano, że po zmianach: Sąd Najwyższy będzie mógł jedynie uchylić zaskarżone orzeczenie i przekazać sprawe do ponownego rozpatrzenia właściwemu sądowi i nie będzie mógł już podejmować [...] rozstrzygnięć, orzekając co do istoty sprawy lub umarzając postępowanie (uzasadnienie, s. 3), wydaje się, iż zamiarem projektodawców jest wprowadzenie takich rozwiązań, zgodnie z którymi orzeczenie będzie uchylane i przekazywane do właściwego sądu także w przypadku, gdy zachodzą przesłanki zawarte w art. $398^{19}$ k.p.c. ${ }^{3}$.

3 Wątpliwości może budzić to, czy zaproponowane w projekcie zmiany są wystarczające do tego, aby przyjęte założenie urzeczywistnić. Na ten temat zob. pismo Prezesa Prokuratorii Generalnej Rzeczypospolitej Polskiej z 11 lipca 2018 r., http://orka.sejm.gov. pl/Druki8ka.nsf/0/CBCC074D9E91BB13C12582CC0044BC09/\%24File/2697-003. pdf, s. 6, gdzie stwierdza się: wyeliminowanie z przepisów podstawy do odrzucenia pozwu lub umorzenia postępowania [tj. art. $398^{19}$ k.p.c. - przyp. R.D.] spowoduje, że w przypadku stwierdzenia przez Sąd Najwyższy niedopuszczalności orzekania i prowa- 


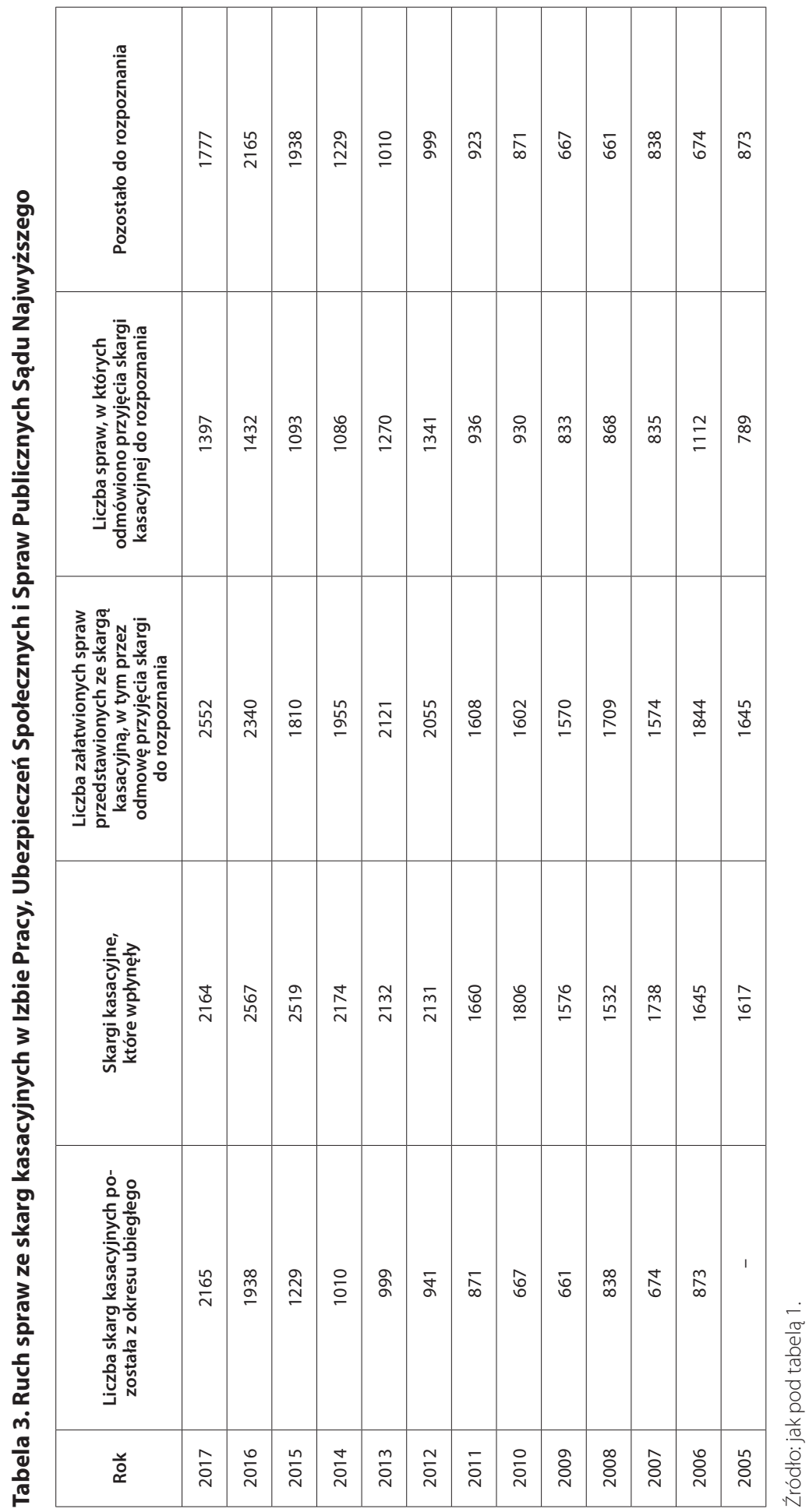


Tabela 4. Odsetek skarg kasacyjnych załatwionych przez odmowę przyjęcia skargi kasacyjnej do rozpoznania w Izbie Pracy, Ubezpieczeń Społecznych i Spraw Publicznych Sądu Najwyższego

\begin{tabular}{|c|c|}
\hline Rok & $\begin{array}{c}\text { Odsetek spraw ze skarg kasacyjnych } \\
\text { załatwionych przez odmowę przyjęcia } \\
\text { skargi kasacyjnej do rozpoznania }\end{array}$ \\
\hline 2017 & 55 \\
\hline 2016 & 61 \\
\hline 2015 & 60 \\
\hline 2014 & 56 \\
\hline 2013 & 60 \\
\hline 2012 & 65 \\
\hline 2011 & 58 \\
\hline 2010 & 58 \\
\hline 2009 & 53 \\
\hline 2008 & 51 \\
\hline 2007 & 53 \\
\hline 2006 & 60 \\
\hline 2005 & 48 \\
\hline
\end{tabular}

Źródło: jak pod tabelą 1.

A zatem różnica między obowiązującym a projektowanym stanem prawnym jest tylko jedna: obecnie wówczas, gdy zachodzą okoliczności, o którym mowa w art. $398^{19}$ k.p.c., SN - uchylając orzeczenie - odrzuca pozew lub umarza postępowanie, natomiast po zmianach - uchylając orzeczenie, musiałby przekazać sprawę do ponownego rozpatrzenia właściwemu sądowi. A zatem nakład pracy potrzebny do ustalenia istnienia lub braku podstaw do uchylenia zaskarżonego orzeczenia pozostałby taki sam. Inne natomiast byłyby czynności podejmowane dopiero po stwierdzeniu okoliczności, o których obecnie mowa w art. $398^{19}$ k.p.c.

dzenia postępowania, nie będzie możliwe jego zakończenie. Wystapienie podstaw do odrzucenia pozwu lub umorzenia postępowania nie oznacza, że skarga kasacyjna jest uzasadniona, więc nie będzie można jej uwzględnić [tj. uchylić i przekazać do ponownego rozpoznania - przyp. R.D.]. Nie będzie możliwe także jej oddalenie, gdyż istnienie bezwzględnych przesłanek procesowych, które uzasadniaja odrzucenie pozwu, z reguty wyklucza merytoryczne orzekanie. 
Również trudno zakładać, że derogowanie art. $398^{16}$ k.p.c., umożliwiającego $\mathrm{SN}$ orzekanie co do istoty sprawy, zrekompensuje skutki zniesienia instytucji przedsądu, ponieważ, jak wskazują dane zawarte w tabeli 5, Izba Cywilna SN średniorocznie tylko w 21 sprawach ze skarg kasacyjnych zmieniła zaskarżone wyroki. A więc nakład pracy związany z samym wydawaniem orzeczeń co do istoty sprawy w skali roku i całej Izby Cywilnej SN nie jest duży.

Tabela 5. Liczba spraw ze skarg kasacyjnych, w których zmieniono wyroki w latach 2005-2017 w Izbie Cywilnej Sądu Najwyższego

\begin{tabular}{|c|c|}
\hline Rok & $\begin{array}{c}\text { Liczba spraw ze skarg kasacyjnych, } \\
\text { w których zmieniono wyroki }\end{array}$ \\
\hline 2017 & 24 \\
\hline 2016 & 9 \\
\hline 2015 & 30 \\
\hline 2014 & 31 \\
\hline 2013 & 28 \\
\hline 2012 & 31 \\
\hline 2011 & 24 \\
\hline 2010 & 29 \\
\hline 2009 & 19 \\
\hline 2008 & 15 \\
\hline 2007 & 9 \\
\hline 2006 & 19 \\
\hline 2005 & 1 \\
\hline
\end{tabular}

Źródło: jak pod tabelą 1.

Nieco więcej wyroków rocznie zmieniano natomiast w Izbie Pracy, Ubezpieczeń Społecznych i Spraw Publicznych SN. Z danych zamieszczonych w tabeli 6 wynika, że w latach 2005-2017 średniorocznie wydawano w tej izbie 38 orzeczeń co do istoty sprawy. Bynajmniej nie jest to jednak taka liczba, która pozwalałaby przypuszczać, że wyeliminowanie możliwości orzekania reformatoryjnego zrównoważy negatywne skutki wywołane zniesieniem instytucji przedsądu.

Zastanawiając się nad tym, czy uchylenie art. $398^{16}$ k.p.c. może zrekompensować obciążenie SN spowodowane wyeliminowaniem przedsądu, trzeba pamiętać, że w świetle obowiązujących przepisów SN może orzec co do istoty sprawy. Nie jest to jednak jego obowiązek. W związku z czym art. $398^{16}$ k.p.c. nie jest czynnikiem generującym dodatkowe obciążenie pracą. A nadto, biorąc pod 
Tabela 6. Liczba spraw ze skarg kasacyjnych, w których zmieniono wyroki w latach 2005-2017 w Izbie Pracy, Ubezpieczeń Społecznych i Spraw Publicznych Sądu Najwyższego

\begin{tabular}{|l|l|}
\hline Rok & $\begin{array}{c}\text { Liczba spraw ze skarg kasacyjnych, } \\
\text { w których zmieniono wyroki }\end{array}$ \\
\hline 2017 & 30 \\
\hline 2016 & 27 \\
\hline 2015 & 19 \\
\hline 2014 & 25 \\
\hline 2013 & 14 \\
\hline 2012 & 20 \\
\hline 2011 & 36 \\
\hline 2010 & 22 \\
\hline 2009 & 59 \\
\hline 2008 & 48 \\
\hline 2007 & 44 \\
\hline 2006 & 70 \\
\hline 2005 & 75 \\
\hline & \\
\hline
\end{tabular}

Źródło: jak pod tabelą 1.

uwagę, że przepis ten może być zastosowany wówczas, gdy podstawa naruszenia prawa materialnego jest oczywiście uzasadniona, a skargi kasacyjnej nie oparto także na podstawie naruszenia przepisów postępowania lub podstawa ta okazała się nieuzasadniona, należy stwierdzić, że orzekanie co do istoty sprawy odbywa się niejako „na marginesie” rozpoznawania skargi kasacyjnej i jest z jej rozpoznawaniem na tyle związane, że orzeczenie co do meritum jest wynikiem analiz i ustaleń poczynionych w toku badania podstaw kasacyjnych.

\section{Podsumowanie}

Na tle przedstawionego projektu dochodzi do konfliktu dwóch społecznie i prawnie istotnych wartości. Jedną z nich jest szybkość postępowania przed SN, drugą zaś - potrzeba zapewnienia ochrony praw i interesów podmiotów wnoszących kasację w przypadku, gdy zostały one naruszone na skutek wydania zaskarżonego orzeczenia. 
Prawdopodobnie skutkiem wprowadzenia projektowanej regulacji będzie wydłużenie czasu trwania postępowań prowadzonych w sprawach ze skarg kasacyjnych, co następnie może w konkretnych przypadkach generować odpowiedzialność odszkodowawczą Skarbu Państwa (m.in. z tytułu przewlekłości postępowania $)^{4}$.

Oczywiście nie jest tak, że tym negatywnym skutkom nie można zapobiec. Jednakże wymagałoby to zmian organizacyjnych w SN. W szczególności, w toku prac nad projektem, warto byłoby rozważyć możliwość zwiększenia liczby etatów sędziowskich lub asystenckich w Izbie Cywilnej oraz Izbie Pracy i Ubezpieczeń Społecznych.

4 Na temat zagrożeń finansowych dla Skarbu Państwa zob. szerzej pismo Prezesa Prokuratorii Generalnej Rzeczypospolitej Polskiej z 11 lipca 2018 r., op. cit., 6-7. 